\title{
Water temperature induces jaw deformity and bone morphogenetic proteins (BMPs) gene expression in golden pompano Trachinotus ovatus larvae
}

\author{
Zhenhua Ma ${ }^{1,2^{*}}$, Nan Zhang ${ }^{1}$, Jian G. Qin ${ }^{3}$, Mingjun Fu' and Shigui Jiang ${ }^{1}$
}

\begin{abstract}
Golden pompano Trachinotus ovatus larvae were kept at 26,29 and $33^{\circ} \mathrm{C}$ for 15 days from 3-day post hatching (DPH) to $18 \mathrm{DPH}$ to test temperature-dependent growth and jaw malformation. The growth, survival, jaw deformity and the gene expressions of bone morphogenetic proteins (BMPs) were used as criteria to examine the fish response to temperature manipulation. The growth rate of fish at 29 or $33^{\circ} \mathrm{C}$ was significantly faster than fish at $26^{\circ} \mathrm{C}$, while fish survival at $29^{\circ} \mathrm{C}$ was significantly higher than fish at $33^{\circ} \mathrm{C}$. Jaw deformity was significantly affected by water temperature. The highest jaw deformity occurred on fish at $33^{\circ} \mathrm{C}$, and the lowest jaw deformity was at $26^{\circ} \mathrm{C}$. The expressions of all BMP genes except BMP10 were significantly affected by water temperature. The highest gene expression of BMP2 was on fish at $29^{\circ} \mathrm{C}$, and the lowest expression was at $33^{\circ} \mathrm{C}$. For the BMP4 gene, the highest and lowest expressions were found on fish at 33 and $26^{\circ} \mathrm{C}$, respectively. The present study indicates that jaw deformity of golden pompano larvae increases with increasing temperature, and the gene expression of BMP4 proteins coincides with high jaw deformity and water temperature elevation.
\end{abstract}

Keywords: Temperature, Jaw deformity, Bone morphogenetic proteins, Golden pompano Trachinotus ovatus

\section{Background}

Temperature is a primary factor affecting early development of fish larvae and can regulate fish metabolism and feeding behavior during fish ontogeny (Kestemont and Baras 2001; Ma 2014). Furthermore, studies have demonstrated that the inappropriate range of temperature can lead to high mortality and body malformation on fish larvae (Lein et al. 1997; Ørnsrud et al. 2004; Ludwig and Lochmann 2009).

Jaw and skeletal malformations are often associated with poor growth and low survival of fish larvae and are a major bottleneck for efficient production of marine fish juveniles for aquaculture (Koumoundouros 2010; Boglione et al. 2013a, b). Jaw malformation can reduce

\footnotetext{
*Correspondence: zhenhua.ma@hotmail.com

1 South China Sea Fisheries Research Institute, Chinese Academy

of Fishery Sciences, Guangzhou 510300, China

Full list of author information is available at the end of the article
}

fish survival and devalue fish quality on market (Barahona-Fernandes 1982; Cobcroft et al. 2004; Ma et al. 2014c). Jaw and skeletal malformations have been frequently observed on fish species in aquaculture such as striped trumpeter Latris lineata (Cobcroft et al. 2012), gilthead sea bream Sparus aurata (Andrades et al. 1996; Prestinicola et al. 2013), and yellowtail kingfish Seriola lalandi (Cobcroft et al. 2004). Lein et al. (1997) demonstrated that the increase of water temperature can induce jaw deformities. Under suboptimal temperatures, significant deformities of gill-cover and skeleton occur on gilthead seabream Sparus aurata (Georgakopoulou et al. 2010) and cranial deformities on European sea bass Dicentrarchus labrax (Georgakopoulou et al. 2007). In golden pompano Trachinotus ovatus, over $33 \%$ of fish population exhibited at least one type of malformation during the larval period (Ma et al. 2014c; Zheng et al. 2014), but it is unclear if temperature leads to jaw deformities in this species. Therefore, it is necessary to 
explore the relationship between temperature and jaw deformity during early ontogeny of golden pompano larvae.

Skeletogenesis is a process of cell differentiation and proliferation in chondrocytes, osteoblasts, osteocytes and osteoclasts, and these cells determine the size, shape and mineral composition of bone structure (Nijweide et al. 1986; Karsenty and Wagner 2002; Phan et al. 2004). The gene expression during skeletogenesis is affected by both genetic and abiotic factors (Boglione et al. 2013a, b). Therefore, unveiling gene networks may provide insights into the potential mechanisms of skeletal malformations. The abiotic and biotic factors could induce skeleton deformity, while the gene expression drives the functional change of organs mediated by environmental factors.

In vertebrates, bone morphogenetic proteins (BMPs) control bone formation at different cell developmental states (e.g., stem cells, proliferative and hypertrophic chondrocytes, maturing osteoblast) (Hogan 1996a, b; Alaee et al. 2014; Windhausen et al. 2015). BMPs are genetically conserved in the animal kingdom, and their biological importance is reflected through functional and structural redundancy of different BMPs in a single species (Razdorov and Vukicevic 2012). For instance, BMPs 1,2 and 3 can stimulate osteoblast, and play an important role in bone fracture healing (Grgurevic et al. 2011). BMPs 2, 4 and 6 are involved in skeletogenesis, especially in differentiation of chondrocytes to form cartilage, and both differentiation and maturation of the chondrocytes in the osteoblastic lineage will give a rise to bone formation (Rickard et al. 1994; Minina et al. 2001; Canalis et al. 2003; Wan and Cao 2005). Although the expression of BMP genes have been studied in several fish species, our understanding on these genes are limited to their discrepant expression at different developmental stage but not on the change body structure and function (Myers et al. 2002; Marques et al. 2014; Palomino et al. 2014; Tiago et al. 2014; Marques et al. 2015). In marine fish, the expression of BMP genes has been studied when fish larvae are under different supply of nutrients such as vitamins and lipids (Villeneuve et al. 2005a, b, 2006). Recently, BMP genes have been used to evaluate the hyperthermic effects on the skeletal malformation of fish larvae (Ytteborg et al. 2010). Up to present, information on the expression of BMPs in golden pompano is rare despite a high frequency of jaw deformation during the period of larval fish development. Investigation on the expression of BMPs in the ontogeny of golden pompano may provide a hint on the reason associated with jaw malformation in fish larvae during osteogenesis.

Golden pompano belongs to the Carangidae family and is a potential species for aquaculture diversification (Guo et al. 2014). Although the early ontogenetic development of digestive functionality (Ma et al. 2014a, b) and weaning strategies have been studied on golden pompano (Ma et al. 2014d), high jaw malformation during the early developmental stages has severely compromised production efficiency of this fish species in hatcheries. Our previous studies have identified the type, position, and frequency of jaw and skeletal malformations in golden pompano larvae (Ma et al. 2014c; Zheng et al. 2014), but factors causing skeletal malformation on this fish have never been evaluated. This paper aims to understand the impact of water temperature on jaw malformation of golden pompano larvae from the perspective of BMP expression on $18 \mathrm{DPH}$ when jaw deformity starts to occur when weaning starts. The results of this study may contribute to improvement of fish quality and production efficiency in farming golden pompano and other marine fish larvae.

\section{Methods}

Fertilized eggs from the same brood cohort were obtained from a fish farm in Lingshui, Hainan Province, and transported to the Tropical Fisheries Research and Development Center, South China Sea Fisheries Research Institute, Chinese Academy of Fishery Science, Xincun Town. Upon arrival, all eggs were transferred into 500-L incubators until hatching. The water temperature was maintained at $26{ }^{\circ} \mathrm{C}$ in the incubators. The experimental design included three constant temperatures 26, 29, and $33{ }^{\circ} \mathrm{C}$ with three replicates each. On 2 days post hatch $(\mathrm{DPH})$, yolk sac larvae were acclimatized at each desired temperature for $5 \mathrm{~h}$, and then stocked in 500-L fiberglass tanks at a density of 60 fish $\mathrm{L}^{-1}$. All rearing tanks were supplied with filtered seawater with a $5-\mu \mathrm{m}$ filter from the bottom of each tank through upwelling with a daily water exchange rate of $200 \%$ tank volume. One air stone was used in each tank to maintain dissolved oxygen close to saturation $\left(6.72 \pm 0.21 \mathrm{mg} \mathrm{L}^{-1}\right)$ and also to promote even distribution of microalgae, rotifers and Artemia nauplii. Light intensity was maintained at 2300 lux (measured at the surface) at the light phase under a photoperiod of 13L:11D. Salinity was maintained at $33 \%$ throughout the experiment. For each temperature treatment, there were three biological replicates, and nine tanks were used. The experiments were conducted in accordance with the guideline and approved by the Ethics Committee of South China Sea Fisheries Research Institute, Chinese Academy of Fishery Sciences (2014YJ01).

\section{Feeding protocol}

Rotifers (Brachionus rotundiformis) were provided to fish larvae from $2 \mathrm{DPH}$ until $13 \mathrm{DPH}$ three times a day at a density of 10 rotifers $\mathrm{mL}^{-1}$. Rotifers were cultured at $25.5{ }^{\circ} \mathrm{C}$. The rotifers fed microalgae (Nannochloropsis 


\begin{tabular}{lll}
$\begin{array}{l}\text { Table } \mathbf{1} \\
\text { study }\end{array}$ & Summary of genes cloning primers used in this \\
\hline Primers & Sequence $\left(\mathbf{5}^{\prime} \mathbf{- 3}^{\prime}\right.$ ) & Amplicon sizes (bp) \\
\hline BMP2-F & CGTGCTGACCAAGACCTAAC & \\
BMP2-R & AACCGGGTGCCATAATAAC & 1549 \\
BMP4-F & GACACCTTCCCTTCACAT & \\
BMP4-R & CAAGTCCAAGTTCTAGTTAGTTT & 1425 \\
BMP5-F & CCAACGAAGACACTACAAGG & \\
BMP5-R & TTAAAGTTAGCCCAGCCACT & 871 \\
BMP10-F & GAAGGACAGTCCTCCCTCAA & \\
BMP10-R & TGCAGCATTGCTTTGCTTTA & 1854 \\
EF-1a-F & TGTTACCTGGCTAGGGG & \\
EF-1a-R & GAGAAGAGGCACCGTCA & 1662 \\
\hline
\end{tabular}

Note for BMP names: $F$ forward primer, $R$ reverse primer

sp.) were enriched with DHA Protein Selco (INVE Aquaculture, Salt Lake City, UT, USA) before the rotifers were added into larval rearing tanks. The enrichment process was followed by the manufacturer's instruction. Instant microalgae paste (Nannochloropsis sp., Qingdao Hong Bang Biological Technology Co., Ltd, Qingdao, China) was also added into larval fish tanks to feed rotifers and also create a green water background for fish larvae. Artemia nauplii enriched with DHA Protein Selco (INVE Aquaculture) were introduced to the fish tank from 9 to $18 \mathrm{DPH}$ at 5 nauplii $\mathrm{mL}^{-1}$.

\section{Growth and survival measurement}

In each tank, 10 fish were sampled for size measurements during 1, 3, 5, 9, 12 and 18 DPH. Fish were anaesthetized with AQUI-S (New Zealand Ltd., Lower Hutt, New Zealand) and were measured on a stereo microscope (Phenix Optical Instrument Group Co., LTD, China) with an eyepiece micrometer at $10 \times$ magnification to the nearest $0.01 \mathrm{~mm}$. Growth was determined by the specific growth rate (SGR) as \%/day using the following equation (Hopkins 1992): $S G R=100\left(\operatorname{LnSL}_{f}-L n S L_{i}\right) / \Delta t$, where $S L_{f}$ and $S L_{i}$ were the final and initial fish standard lengths $(\mathrm{mm})$, respectively, and $\Delta t$ was the time between sampling intervals. At the end of this experiment, fish from each rearing tanks were harvested and counted for the final survival. Degree-days $\left(\mathrm{D}^{\circ}\right)$ was calculated using following equation: $\mathrm{D}^{\mathrm{o}}=\Delta \mathrm{t} \times \mathrm{T}$, where $\mathrm{T}$ was the rearing temperature $\left({ }^{\circ} \mathrm{C}\right)$ and $\Delta \mathrm{t}$ is the period of time in days.

\section{Jaw malformation}

At the end of this experiment, 100 fish larvae were randomly collected from each rearing tank to examine the incidence of malformation. Fish were anaesthetized with overdosed Aqui-S (AQUI-S New Zealand Ltd., Lower Hutt, New Zealand) and fixed in $10 \%$ neutrally buffered formalin. Jaw deformity was directly assessed on a stereo microscope (Olympus SZ40, Tokyo, Japan) using the criteria described by $\mathrm{Ma}$ et al. (2014c). Jaw malformation (\%) was calculated by the following equation: Jaw malformation $=($ malformed larvae $/$ total larvae $) \times 100$.

\section{Total RNA extraction and reverse transcription}

Approximately 50 individuals were collected from each rearing tank on $18 \mathrm{DPH}$. Total RNA was extracted using TRIzol Reagent (Invitrogen, USA) according to the manufacture protocol. RNA integrity was verified by electrophoresis on a formaldehyde-agarose gel $(1.2 \%)$. The RNA concentration was measured by absorbance at $260 \mathrm{~nm}$ and the purity was determined at the OD 260/280 ratio $(1.7<$ OD260/OD280 < 2.0), OD 260/230 ratio $(2.0<\mathrm{OD} 260 / \mathrm{OD} 230<2.5)$ and agarose gel electrophoresis. RNA was reverse-transcribed to cDNA with oligo (dT) primers using a PrimeScript 1st strand cDNA synthesis kit (TaKaRa Biotechnology, Dalian Co., Ltd). The cDNA was used as a template in subsequent PCR. The cDNAs for quantitative real-time PCR were synthesized from one microgram of the total RNA of each sample using the PrimeScript $^{\mathrm{TM}} \mathrm{RT}$ reagent kit with gDNA Eraser (TaKaRa).

\section{Gene cloning}

Based on unpublished golden pompano transcriptome sequences (Illumina HiSeq 2000, annotated by NR, KOG, kegg, and Swissprot), the genes cloning primers were designed (shown in Table 1). The reagents for PCR reaction included $1 \mu \mathrm{L}$ of golden pompano larval cDNA, $1 \mu \mathrm{L}$ of gene-specific forward primer $(\mathrm{F}, 10 \mu \mathrm{mol} \mathrm{L}-1)$, $1 \mu \mathrm{L}$ of gene-specific reverse primer $\left(\mathrm{R}, 10 \mu \mathrm{mol} \mathrm{L} \mathrm{L}^{-1}\right)$, $0.5 \mu \mathrm{L}$ of ExTaq, $5 \mu \mathrm{L}$ of PCR buffer and $4 \mu \mathrm{L}$ of dNTP mixture $(2.5 \mu \mathrm{M}), 37.5 \mu \mathrm{L}$ of $\mathrm{dd}_{2} \mathrm{O}$ in a total volume of $50 \mu \mathrm{L}$. The PCR conditions were as follows: denaturation at $94{ }^{\circ} \mathrm{C}$ for $1 \mathrm{~min}, 35$-cycles of $94{ }^{\circ} \mathrm{C}$ for $30 \mathrm{~s}$, annealing temperature of each genes for $30 \mathrm{~s}, 72{ }^{\circ} \mathrm{C}$ for $4 \mathrm{~min}$, followed by a $10 \mathrm{~min}$ extension at $72{ }^{\circ} \mathrm{C}$. The PCR products were cloned into the PMD-19T vector (TaKaRa Biotechnology, Dalian Co., Ltd), and then were sequenced.

\section{Gene expression analysis by quantitative real-time PCR}

Quantitative real-time PCR (qPCR) was used to analyze the expression levels of BMP genes in golden pompano larvae. Gene specific primer pairs for BMP genes (Table 2) were amplified in LightCycler480 II (Roche, Switzerland). The EF-1 $\alpha$ (GenBank Accession NO. KT727924) was used as the reference and amplified. The cycling conditions for the BMP genes and EF $1 \alpha$ were as follows: $1 \mathrm{~min}$ at $95^{\circ} \mathrm{C}$, followed by 40 cycles at $95{ }^{\circ} \mathrm{C}$ for $15 \mathrm{~s}$, and $60{ }^{\circ} \mathrm{C}$ for $1 \mathrm{~min}$. Dissociation curves were employed to ensure that only one single PCR product was amplified in each gene reaction. For each test, 
Table 2 Summary of quantitative real-time PCR primers used in this study

\begin{tabular}{lll}
\hline Primers & Sequence $\left(\mathbf{5}^{\prime} \mathbf{- 3}^{\prime} \mathbf{)}\right.$ & $\begin{array}{l}\text { Amplicon } \\
\text { sizes } \mathbf{( b p )}\end{array}$ \\
\hline BMP2-qF & CAGGCAGCACTCCGCAAAC & \\
BMP2-qR & TCCCCGTGGCAGTAAAAGG & 146 \\
BMP4-qF & GTGAACAACAACATTCCCAAGG & \\
BMP4-qR & GCAGCCCTCCACTACCATTT & 126 \\
BMP5-qF & GTGGAGACTGTAGACGGACGAA & \\
BMP5-qR & TGAAGAAAGCAACCAGGAAGG & 100 \\
BMP10-qF & CCGCTTCAGTCTTCTCCAACC & \\
BMP10-qR & CGGATTATCACCCACATCCCTA & 149 \\
EF-1a-qF & CCCCTTGGTCGTTTGCC & \\
EF-1a-qR & GCCTTGGTTGTCTTTCCGCTA & 101
\end{tabular}

Note for BMP names: $q F$ forward primer for real-time $P C R, q R$ reverse primer for real time $P C R$

Table 3 Specific growth rate, survival, and jaw deformity rate of golden pompano larvae cultured at 26,29 , and $33^{\circ} \mathrm{C}$

\begin{tabular}{lcrr}
\hline & \multicolumn{2}{c}{$\mathbf{2 6}{ }^{\circ} \mathbf{C}$} & \multicolumn{2}{c}{$\mathbf{2 9}{ }^{\circ} \mathbf{C}$} & \multicolumn{1}{c}{$\mathbf{3 3 ^ { \circ } \mathbf { C }}$} \\
\hline $\begin{array}{l}\text { Specific growth rate } \\
\text { (\%/day) }\end{array}$ & $2.70 \pm 0.42^{\mathrm{a}}$ & $3.64 \pm 0.20^{\mathrm{b}}$ & $4.31 \pm 0.74^{\mathrm{b}}$ \\
Survival (\%) & $10.30 \pm 0.41^{\mathrm{a}, \mathrm{b}}$ & $11.36 \pm 1.08^{\mathrm{b}}$ & $9.57 \pm 0.23^{\mathrm{a}}$ \\
Jaw deformity rate (\%) & $5.00 \pm 0.64^{\mathrm{a}}$ & $10 \pm 2.65^{\mathrm{b}}$ & $20.00 \pm 3.54^{\mathrm{c}}$
\end{tabular}

Different lowercase letters (i.e., $a, b$ and c) indicate statistically significant differences $(P<0.05$

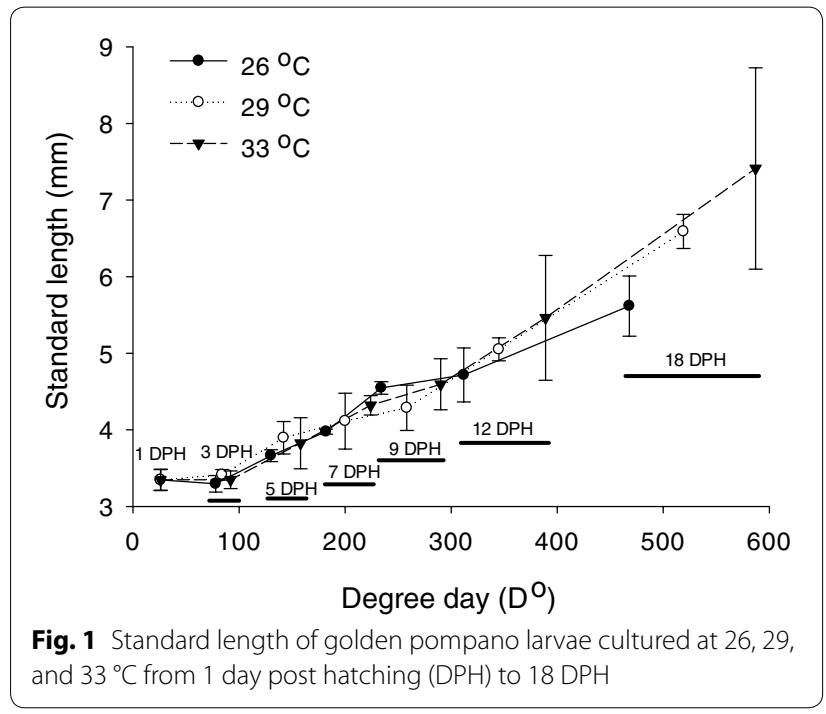

three replicates were performed. The relative quantification (RQ) was calculated using the ${ }^{\Delta \Delta} \mathrm{CT}$ (comparative threshold cycle) method $\left({ }^{\Delta} \mathrm{CT}=\mathrm{CT}\right.$ of target gene $-\mathrm{CT}$ of EF-1 $\alpha,{ }^{\Delta \Delta} \mathrm{CT}={ }^{\Delta} \mathrm{CT}$ of any sample $-{ }^{\Delta} \mathrm{CT}$ of calibrator sample). The efficiencies of the primers (E) were $\mathrm{E}_{\mathrm{BMP} 2}=0.998, \mathrm{E}_{\mathrm{BMP} 4}=1.004, \mathrm{E}_{\mathrm{BMP} 5}=0.923$, $\mathrm{E}_{\mathrm{BMP} 10}=1.004$.

\section{Statistical analysis}

All percentage data were arcsine-transformed prior to statistical analysis. However, the data were presented as untransformed values in figures. The data were all expressed as mean $\pm \mathrm{SD}$, and compared with one way ANOVA (PASW Statistics 18.0, Chicago, SPSS Inc.). When a significant treatment effect was found, Tukey's test was performed for multiple range comparisons with the level of significant difference set at $P<0.05$. All data were tested for normality, homogeneity and independence to satisfy the assumptions of ANOVA.

\section{Results}

\section{Growth performance, survival and jaw deformities}

At the end of this experiment, the standard length of fish larvae at 26,29 , and $33{ }^{\circ} \mathrm{C}$ were $5.62 \pm 0.39,6.59 \pm 0.22$, and $7.41 \pm 1.31 \mathrm{~mm}$, respectively. Temperature significantly affected the growth of golden pompano larvae $(P<0.05$, Table 3$)$. The SGRs of fish at 29 and $33{ }^{\circ} \mathrm{C}$ were $3.64 \pm 0.20$ and $4.31 \pm 0.74 \% /$ day, respectively, which were significantly higher than those reared at $26{ }^{\circ} \mathrm{C}$ $(P<0.05)$. The SGR of fish was not significantly different between fish at 29 and $33{ }^{\circ} \mathrm{C}(P>0.05)$. During the ontogenetic development, the variation of fish length on each sampling day increased with the increase of degreedays (Fig. 1). In this study, the growth of newly hatched golden pompano was slow before 234 degree-day $\left(\mathrm{D}^{\circ}\right)$ on $9 \mathrm{DPH}$. When the number of degree-days reached 312$389 \mathrm{D}^{\circ}(12 \mathrm{DPH})$, the size of fish larvae gradually became different between temperature treatments. When the degree-days reached $468-587 \mathrm{D}^{\circ}(18 \mathrm{DPH})$, fish growth was clearly affected by water temperature, and fish growth was accelerated when temperature increased from 29 to $33^{\circ} \mathrm{C}$.

Rearing temperature significantly affected the survival of golden pompano larvae $(P<0.05$, Table 3$)$. The highest survival was achieved in fish at $29^{\circ} \mathrm{C}$, and the lowest survival was observed in fish at $33^{\circ} \mathrm{C}$. In this study, water temperature significantly affected fish jaw deformities $(P<0.05$, Table 3$)$. Jaw deformity of fish at $33^{\circ} \mathrm{C}$ was $20.00 \pm 3.54 \%$, which was significantly higher than the deformity rates of fish at 26 and $29{ }^{\circ} \mathrm{C}(P<0.05)$. The lowest jaw deformity rate was observed in fish reared at $26^{\circ} \mathrm{C}$.

\section{Expression of BMPs in fish at different temperatures}

Partial sequences of BMP2 (GenBank Accession NO. KT727918), BMP4 (GenBank Accession NO. KT727919), BMP5 (GenBank Accession NO. KT727921), and BMP10 (GenBank Accession NO. KT727920) genes were obtained after sequencing analysis (Appendices 1-4). Water temperature significantly affected the expressions of BMP2, BMP4 and BMP5 genes in golden pompano 


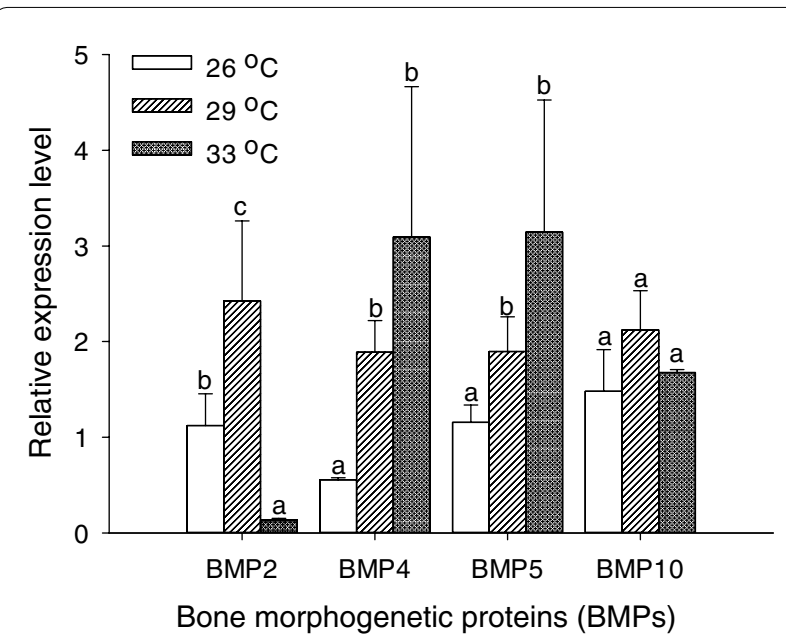

Fig. 2 Relative expression levels of bone morphogenetic proteins of golden pompano larvae at different temperatures on $18 \mathrm{DPH}$. The level of gene expression at $26^{\circ} \mathrm{C}$ was served as the control for BMP2, BMP4, BMP5, and BMP10, respectively

larvae $(P<0.05$, Fig. 2$)$. In the gene expression of BMP2, the highest expression was found in fish at $29^{\circ} \mathrm{C}$, and the lowest expression was in fish at $33^{\circ} \mathrm{C}$. In the gene expressions of BMP4 and BMP5, the expression levels were not significantly different between fish at 29 and $33{ }^{\circ} \mathrm{C}$ $(P>0.05)$, but were significantly higher than fish reared at $26{ }^{\circ} \mathrm{C}(P<0.05$, Fig. 2$)$. On $18 \mathrm{DPH}$, the expression of BMP10 in golden pompano larvae was not significantly affected by the rearing temperature $(P>0.05)$.

\section{Discussion}

\section{Growth and survival of fish larvae}

Water temperature is a critical factor for the success of fish hatchery production, and it has significant implication on the growth performance of fish larvae (Boglione et al. 2013b). Temperature can regulate fish metabolism, food intake and growth (Jobling 1994; Ma 2014), and the effects of temperature on fish growth have been well documented in the larvae of commercially important fish species including haddock Melanogrammus aeglefinus L. (Martell et al. 2005), nase Chondrostoma nasus L. (Keckeis et al. 2001), Australian snapper Pagrus auratus (Fielder et al. 2005), striped trumpeter Latris lineata (Choa et al. 2010), and yellowtail kingfish Seriola lalandi (Ma 2014). In golden pompano, the fast growth at high temperature may be attributed to the improved food ingestion and digestive function of fish larvae after 15 DPH as Ma et al. (2014b) reported that the goblet cells and gastric glands appeared in the gut of golden pompano larvae after $15 \mathrm{DPH}$ at $27-29^{\circ} \mathrm{C}$. The growth of fish larvae tended to be accelerated when fish were weaned from rotifers to Artemia nauplii. Similar to the Florida pompano Trachinotus carolinus (Riley et al. 2009), the length of mouth gape close to $1.05 \mathrm{~mm}$ should allow golden pompano larvae to ingest Artemia nauplii and other similar size of food particles by $12 \mathrm{DPH}$. Therefore, the significant difference in fish size between thermal treatments at $18 \mathrm{DPH}$ may be also related to the use of high energy food from 9 DPH onwards.

In both wild and artificial environments, fish mortality is often observed at the critical period of nutritional transition from endogenous to exogenous feeding (Otterlei et al. 1999; Ma et al. 2012). During the period of food transition, when the food supply and light condition are optimal, temperature can be a key determinant for fish survival (McGurk 1984; Kamler 1992; Gardeur et al. 2007; Ma 2014). Previous studies have demonstrated that mortality is strongly temperature-dependent in the larvae and juveniles of Seriola lalandi (Ma 2014), Pangasianodon hypophthalmus (Baras et al. 2011), Inimicus japonicas (Wen et al. 2013), and Glyptocephalus cynoglossus (Bidwell and Howell 2001). Ma (2014) suggests that there is a temperature-sensitive period during early ontogeny where mortality is likely to occur in fish larvae. In the present study, lower survival was observed when fish were reared at $33{ }^{\circ} \mathrm{C}$ than at other temperatures, suggesting the importance of temperature for golden pompano larval rearing. In the present study, the fish density was reduced at high temperatures due to high mortality, which may contribute to temperature-dependent fish growth in this study.

\section{Temperature effect on jaw malformation}

Jaw malformation is a major concern in fish culture because it affects fish morphology and quality at the growout stage (Von Westernhagen 1988). In the present study, the proportion of fish larvae exhibiting jaw deformities increased with the increase of water temperature, and peaked at $33{ }^{\circ} \mathrm{C}$. Similar results have also been found in other fish species such as Atlantic halibut Hippoglossus hippoglossus (Lein et al. 1997) and Pacific herring Clupea pallasi (Alderdice and Velsen 1971). Such a temperature-dependent developmental pattern is generally attributed to high oxygen (Rombough 1997) and high nutritional requirements at high temperatures, which may not be fulfilled unless the feed with high energy or protein contents is provided (Cahu et al. 2003a, b; Ma 2014). Furthemore, temperature fluctuation might also interfere with the harmonic development of functional organs such as the digestive tract and skeleton, leading to skeletal deformities at high temperature. In the present study, fertilized fish eggs hatched at $26{ }^{\circ} \mathrm{C}$, and yolk sac larvae were acclimatized at each desired temperature for $5 \mathrm{~h}$ on $2 \mathrm{DPH}$. The quick increase of rearing temperature from 26 to 29 or $33{ }^{\circ} \mathrm{C}$ may affect skeletogenesis and induce jaw deformity. 


\section{BMP gene expression at different temperatures}

The present study was design to evaluate the effects of temperature appear to be specific to certain BMP family members impacting bone formation. The growth of skeleton relies on the dynamic equilibrium between cartilage production and bone apposition rate (Breur et al. 1991). The BMP2 and BMP4 proteins are involved in processes of dorsal-ventral axis specification (Graff 1997), epithelio-mesenchymal interactions (Vainio et al. 1993), and apoptosis (Graham et al. 1994; Glozak and Rogers 1996; Zou and Niswander 1996). The BMP2 gene in zebrafish is related to the induction and maintenance of ventro-lateral cell fate during early development, while a missense mutation in the BMP2b gene can lead to the early dorsalized phenotype of the zebrafish swirl mutant which lacks the cardiogenic mesoderm (Kishimoto et al. 1997). Ytteborg et al. (2010) found that the expression of BMP2 was up-regulated when fish was under a hyperthermic condition. In the present study, the expression of BMP2 in fish reared at $29{ }^{\circ} \mathrm{C}$ showed a up-regulating trend comparing to the expreesion of BMP2 in fish reared at $26{ }^{\circ} \mathrm{C}$, which is consistent with the results reported by Ytteborg et al. (2010). However, the reason for low expression of BMP2 in fish at $33^{\circ} \mathrm{C}$ is unclear.

BMP4 plays a diverse role during vertebrate development (Hogan 1996b; Mehler et al. 1997; Whitman 1998; Dale and Johns 1999; Shi and Massague 2003), and has been used to evaluate if the BMP metabolic pathway is related to skeletal deformities under an unbalanced nutritional supply (Villeneuve et al. 2005a, b, 2006) (Ytteborg et al. 2010). Villeneuve et al. (2006) suggested that the increase of BMP4 and RARy expression can reduce the number of osteoblasts available for bone formation and that the loss of bone cells is counterbalanced by the cooperation between retinoic acid and BMP4. In the present study, the expression of BMP4 in fish at 29 and $33^{\circ} \mathrm{C}$ increased significantly, and jaw deformities at these two temperatures were significantly higher than fish at $26{ }^{\circ} \mathrm{C}$. This result supports to the notion that the expression of BMP4 tends to increase when fish are reared at a high temperature (Ytteborg et al. 2010), and the proportion of jaw deformities in fish larvae increases when the expression of BMP4 in fish shows a trend of up-regulation (Villeneuve et al. 2006). However, to confirm this result, future research should evaluate the gene expression in the jaw and conduct in situ hybridization analysis and mineralization analysis.

Previous studies indicate that the 60A subgroup (BMPs5, 6 and 7) is functionally redundant and that the collective expression of the 60A subgroup determines developmental function (Solloway and Robertson 1999; Kim et al. 2001). Specifically, BMP5 can be expressed during endochondral ossification, inducing condensation of mesenchymal cells to chondrocytes (King et al. 1994; Bailon-Plaza et al. 1999). Furthermore, the mutated BMP5 gene can lead to skeletal and bone abnormalities, suggesting the importance of BMP5 in skeletal development (Kingsley et al. 1992; Storm et al. 1994; Wolfman et al. 2003). In the present study, the expression pattern of BMP5 was similar to that observed in BMP4. The expression level of BMP5 in fish at 29 or $33^{\circ} \mathrm{C}$ was significantly higher than that at $26^{\circ} \mathrm{C}$. Although the expression of BMP5 increased with increasing temperatures and the occurrence of jaw deformity, it is unclear if deformity and high temperature are concomitant events in fish.

Existing literature indicates that the BMP10 gene plays little role in craniofacial or bone development. The BMP10 gene is expressed predominantly in the adult heart and to a lesser extent in the liver and lung (Neuhaus et al. 1999). During heart development, BMP10 is expressed in the trabeculae of the bulbus cordis, the common ventricular chamber, and of the atrium (Neuhaus et al. 1999). In zebrafish, relatively high BMP10 expression occurs in the heart and liver, but low expression is detected in the brain, and kidney (Bland 2001). In the present study, the expression of BMP10 was not significantly affected by the rearing temperature. This may suggest that the expression of BMP10 in golden pompano larvae is not sensitive to temperature by $18 \mathrm{DPH}$.

\section{Conclusion}

In summary, the present study examined the effect of temperature on the jaw deformity in golden pompano larvae. Jaw deformity in fish larvae increased with the increase of water temperature, and peaked at $33{ }^{\circ} \mathrm{C}$. This study suggests that the rearing temperature of golden pompano larvae should be controlled at $26-29^{\circ} \mathrm{C}$ and the expression levels of BMP4 and BMP5 genes are positively synchronized with the occurrence of jaw deformities.

\section{Authors' contributions}

ZM, NZ, MF, SJ, and JG designed and run the experiment, ZM, MF, and JGQ analysis the sample and finalized the manuscript. All authors read and approved the final manuscript.

\section{Author details \\ ${ }^{1}$ South China Sea Fisheries Research Institute, Chinese Academy of Fishery Sciences, Guangzhou 510300, China. ${ }^{2}$ Key Laboratory of South China Sea Fishery Resources Exploitation and Utilization, Ministry of Agriculture, Guang- zhou 510300, China. ${ }^{3}$ School of Biological Sciences, Flinders University, GPO Box 2100, Adelaide, SA 5001, Australia.}

\section{Acknowledgements}

This project was funded by National Natural Science Foundation of China (31502186), Ministry of Human Resources and Social Security of China (2016 High-level Overseas Researcher Come Back to Work Funds), Pearl River S\&T Nova Program of Guangzhou (201610010166), and Special Scientific Research Funds for Central Non-profit Institutes, South China Sea Fisheries Research Institute, Chinese Academy of Fishery Sciences (2014YJ01).

\section{Competing interests}

The authors declare that they have no competing interests. 


\section{Appendix 1: Partial sequences of BMP2}

1 CGTGCTGACCAAGACCTAACCCGAACTGCAGCTGGTGAGAATATGTGCGAGAGGCGATCG 60

61 GCGAAGGGCATGGGCTGTCTCTGGTCCCCCAAGGAGAAGCAGCGTGGATTAAACACGAAT 120

121 TAATGTGGAATTTATCGGAGCCCAAAGGTGGAACGACGACCGGACACAGCGCTTCCTCGT 180

181 CAGGGACTGACTGATCatggtcgecgtggtccgctctctcatggtactgctgctcgctca 240

$\begin{array}{lllllllllllllllll}1 & \text { M } & \text { V } & \text { A } & \text { V } & \text { V } & \text { R } & \text { S } & \text { L } & \text { M } & \text { V } & \text { L } & \text { L } & \text { L } & \text { A } & \text { Q } & 15\end{array}$

241 ggtgttgctggaaggtgctacgggactaatccccgaggtcggccggaggaaatatagcga 300

$\begin{array}{llllllllllllllllllllll}16 & \mathrm{~V} & \mathrm{~L} & \mathrm{~L} & \mathrm{E} & \mathrm{G} & \mathrm{A} & \mathrm{T} & \mathrm{G} & \mathrm{L} & \mathrm{I} & \mathrm{P} & \mathrm{E} & \mathrm{V} & \mathrm{G} & \mathrm{R} & \mathrm{R} & \mathrm{K} & \mathrm{Y} & \mathrm{S} & \mathrm{E} & 35\end{array}$

301 atccgggaagcagaccceggagcagtcggagagcttcctcaacgagtttgagcttcggct 360

$\begin{array}{llllllllllllllllllllll}36 & \mathrm{~S} & \mathrm{G} & \mathrm{K} & \mathrm{Q} & \mathrm{T} & \mathrm{P} & \mathrm{E} & \mathrm{Q} & \mathrm{S} & \mathrm{E} & \mathrm{S} & \mathrm{F} & \mathrm{L} & \mathrm{N} & \mathrm{E} & \mathrm{F} & \mathrm{E} & \mathrm{L} & \mathrm{R} & \mathrm{L} & 55\end{array}$

361 tctcaatatgtttggactgaggcgcaggccgaccccgagcaagcaagccgtggtgccgca 420

$\begin{array}{llllllllllllllllllllll}56 & \mathrm{~L} & \mathrm{~N} & \mathrm{M} & \mathrm{F} & \mathrm{G} & \mathrm{L} & \mathrm{R} & \mathrm{R} & \mathrm{R} & \mathrm{P} & \mathrm{T} & \mathrm{P} & \mathrm{S} & \mathrm{K} & \mathrm{Q} & \mathrm{A} & \mathrm{V} & \mathrm{V} & \mathrm{P} & \mathrm{Q} & 75\end{array}$

421 gtacatggtggacctttaccgcatgcactcagcgaacggagaccacagcactaaacgacc 480

$\begin{array}{llllllllllllllllllllll}76 & \text { Y } & \text { M } & \text { V } & \text { D } & \text { L } & \text { Y } & \text { R } & \text { M } & \text { H } & \text { S } & \text { A } & \text { N } & \text { G } & \text { D } & \text { H } & \text { S } & \text { T } & \text { K } & \text { R } & \text { P } & 95\end{array}$

481 caagagcatggggaaacacgcagatagagccgccagcaaggccaacacgattagaagctt 540

$\begin{array}{llllllllllllllllllllll}96 & K & \text { S } & \text { M } & \text { G } & \text { K } & \text { H } & \text { A } & \text { D } & \text { R } & \text { A } & \text { A } & \text { S } & \text { K } & \text { A } & \text { N } & \text { T } & \text { I } & \text { R } & \text { S } & \text { F } & 115\end{array}$

541 tcaccatgaagagtccatggaggccttggccagcctgaaaggcaaaacgacccagcagtt 600

$\begin{array}{llllllllllllllllllllll}116 & \mathrm{H} & \mathrm{H} & \mathrm{E} & \mathrm{E} & \mathrm{S} & \mathrm{M} & \mathrm{E} & \mathrm{A} & \mathrm{L} & \mathrm{A} & \mathrm{S} & \mathrm{L} & \mathrm{K} & \mathrm{G} & \mathrm{K} & \mathrm{T} & \mathrm{T} & \mathrm{Q} & \mathrm{Q} & \mathrm{F} & 135\end{array}$

601 ctacttcaacctcacttctatccetgatgaggagctcatcacctctgcagagctacgtat 660

$\begin{array}{llllllllllllllllllllll}136 & \text { Y } & \text { F } & \text { N } & \text { L } & \text { T } & \text { S } & \text { I } & \text { P } & \text { D } & \text { E } & \text { E } & \text { L } & \text { I } & \text { T } & \text { S } & \text { A } & \text { E } & \text { L } & \text { R } & \text { I } & 155\end{array}$

661 ctacagggatcaggtcctgggagctgcaacccctagcaacagctccagaaacagcagcac 720

$\begin{array}{llllllllllllllllllllll}156 & \text { Y } & \text { R } & \text { D } & \text { Q } & \text { V } & \text { L } & \text { G } & \text { A } & \text { A } & \text { T } & \text { P } & \text { S } & \text { N } & \text { S } & \text { S } & \text { R } & \text { N } & \text { S } & \text { S } & \text { T } & 175\end{array}$

721 cagtgatagtggtcctgctgcgggtttccatcgtatcaacatttatgagatattcggagt 780

$\begin{array}{llllllllllllllllllllll}176 & \text { S } & \text { D } & \text { S } & G & \text { P } & \text { A } & \text { A } & \text { G } & \text { F } & \text { H } & \text { R } & \text { I } & \text { N } & \text { I } & \text { Y } & \text { E } & \text { I } & \text { F } & \text { G } & \text { V } & 195\end{array}$

781 tccttccactgatggtggggaacctctggcacgtctgctggacactcggctagtgcagga 840

$\begin{array}{llllllllllllllllllllll}196 & \text { P } & \text { S } & \text { T } & \text { D } & G & G & \text { E } & \text { P } & \text { L } & \text { A } & \text { R } & \text { L } & \text { L } & \text { D } & \text { T } & \text { R } & \text { L } & \text { V } & \text { Q } & \text { D } & 215\end{array}$

841 ctctttaagccgctgggagagctttgacgtcagcccagctgtatctcagtggacctccgg 900

$\begin{array}{llllllllllllllllllllll}216 & \text { S } & \text { L } & \text { S } & \text { R } & \text { W } & \text { E } & \text { S } & \text { F } & \text { D } & \text { V } & \text { S } & \text { P } & \text { A } & \text { V } & \text { S } & \text { Q } & \text { W } & \text { T } & \text { S } & \text { G } & 235\end{array}$

901 caaaggccacaaccatggcttcatggtggaggtacttcacccagaggaaggggagatgga 960

$\begin{array}{llllllllllllllllllllll}236 & \text { K } & \text { G } & H & \text { N } & \text { H } & \text { G } & \text { F } & \text { M } & \text { V } & \text { E } & \text { V } & \text { L } & \text { H } & \text { P } & \text { E } & \text { E } & \text { G } & \text { E } & \text { M } & \text { D } & 255\end{array}$

961 tggagagcatgcccagagacgtagtaggcatgtcagggtgagccggtccctgcaccagga 1020

$\begin{array}{llllllllllllllllllllll}256 & G & \text { E } & \text { H } & \text { A } & \text { Q } & \text { R } & \text { R } & \text { S } & \text { R } & \text { H } & \text { V } & \text { R } & \text { V } & \text { S } & \text { R } & \text { S } & \text { L } & \text { H } & \text { Q } & \text { D } & 275\end{array}$

1021 ccaggactcatggcctcaggctcggccettgctggtgacgtacggtcacgacggccgtgg 1080

$\begin{array}{llllllllllllllllllllll}276 & \text { Q } & \text { D } & \text { S } & \text { W } & \text { P } & \text { Q } & \text { A } & \text { R } & \text { P } & \text { L } & \text { L } & \text { V } & \text { T } & \text { Y } & \text { G } & \text { H } & \text { D } & \text { G } & \text { R } & \text { G } & 295\end{array}$

1081 ggactcagtactccacacacgagaaaaacgtcaggcagcactccgcaaacaacgcagaaa 1140

$\begin{array}{llllllllllllllllllllll}296 & \text { D } & \text { S } & \text { V } & \text { L } & \text { H } & \text { T } & \text { R } & \text { E } & \text { K } & \text { R } & \text { Q } & \text { A } & \text { A } & \text { L } & \text { R } & \text { K } & \text { Q } & \text { R } & \text { R } & \text { K } & 315\end{array}$

1141 gcaacagcacaaggcaagctgcaagaggcatgccctgtatgtggacttcagtgatgtggg 1200

$\begin{array}{llllllllllllllllllllll}316 & \text { Q } & \text { Q } & \text { H } & \text { K } & \text { A } & \text { S } & \text { C } & \text { K } & \text { R } & \text { H } & \text { A } & \text { L } & \text { Y } & \text { V } & \text { D } & \text { F } & \text { S } & \text { D } & \text { V } & \text { G } & 335\end{array}$

1201 gtggaacgagtggatagtggcacccctggttaccacgccttttactgccacggggaatg 1260

$\begin{array}{llllllllllllllllllllll}336 & \text { W } & \text { N } & \text { E } & \text { W } & \text { I } & \text { V } & \text { A } & \text { P } & \text { P } & \text { G } & \text { Y } & \text { H } & \text { A } & \text { F } & \text { Y } & \text { C } & \text { H } & \text { G } & \text { E } & \text { C } & 355\end{array}$

1261 tccgttcccctagcagaccacctcaattctaccaatcatgccattgtgcagacgctggt 1320

$\begin{array}{llllllllllllllllllllll}356 & \text { P } & \text { F } & \text { P } & \text { L } & \text { A } & \text { D } & \text { H } & \text { L } & \text { N } & \text { S } & \text { T } & \text { N } & \text { H } & \text { A } & \text { I } & \text { V } & \text { Q } & \text { T } & \text { L } & \text { V } & 375\end{array}$

1321 caactcagtcaactcaaacatccccagagcctgttgtgtccctactgacctcagccccat 1380

$\begin{array}{llllllllllllllllllllll}376 & N & \text { S } & \text { V } & \text { N } & \text { S } & \text { N } & \text { I } & \text { P } & \text { R } & \text { A } & \text { C } & \text { C } & \text { V } & \text { P } & \text { T } & \text { D } & \text { L } & \text { S } & \text { P } & \text { I } & 395\end{array}$

1381 ctccctgctctact tggatgaatatgagaaggtcatcctgaaaaactaccaggacatggt 1440

$\begin{array}{llllllllllllllllllllll}396 & \text { S } & \text { L } & \text { L } & \text { Y } & \text { L } & \text { D } & \text { E } & \text { Y } & \text { E } & \text { K } & \text { V } & \text { I } & \text { L } & \text { K } & \text { N } & \text { Y } & \text { Q } & \text { D } & \text { M } & \text { V } & 415\end{array}$

1441 ggtggagggatgtggctgccggtgaGCAACTGACAGTGGTATGGATAGAAAGAAAGAGTG 1500

$\begin{array}{llllllllll}416 & \mathrm{~V} & \mathrm{E} & \mathrm{G} & \mathrm{C} & \mathrm{G} & \mathrm{C} & \mathrm{R} & * & 422\end{array}$

1501 GGCAAGAAAGACTGAGAGAGGCATCAGAGGTTATTATGGACACCCGGTT 1549 


\section{Appendix 2: Partial sequences of BMP4}

1 GACACCTTCCCTTTCACATTCACTCCATTCGAGGATACCTGTACCTCTACTGATGGAACA 60

61 GGGTCACTCCAACGTTCTCCTGCAGCCGCCCAACACCACCTAACATTTCCTGGAAAAACG 120

121 TGTCCATTGCCTCCTCCCAACAAACATGGACTGTTTTCCCATGCTTTATTTTCTGTCGAG 180

181 ACATCatgattcctggtaatcgaatgctgatggtcattttaatatgccaagtcctgctgg 240

$\begin{array}{lllllllllllllllllllll}1 & \text { M } & \text { I } & \text { P } & \text { G } & \text { N } & \text { R } & \text { M } & \text { L } & \text { M } & \text { V } & \text { I } & \text { L } & \text { I } & \text { C } & \text { Q } & \text { V } & \text { L } & \text { L } & \text { G } & 19\end{array}$

241 gagagagtaaccatgctagtctgatacctgaagaagggaaaaagaaagtaccgggcctgc 300

$\begin{array}{llllllllllllllllllllll}20 & \text { E } & \text { S } & \text { N } & \text { H } & \text { A } & \text { S } & \text { L } & \text { I } & \text { P } & \text { E } & \text { E } & \text { G } & \text { K } & \text { K } & \text { K } & \text { V } & \text { P } & \text { G } & \text { L } & \text { Q } & 39\end{array}$

301 agggtcgttcggccgctcagagccatgaactgctgcgggacttcgaggccacgctgctgc 360

$\begin{array}{llllllllllllllllllllll}40 & G & R & S & A & A & Q & S & H & E & \text { L } & \text { L } & \text { R } & \text { D } & \text { F } & \text { E } & \text { A } & \text { T } & \text { L } & \text { L } & \text { H } & 59\end{array}$

361 acatgttcggcctcaagaggcggccgcggcccagccgctccaccaccgtgccccgctacc 420

$\begin{array}{llllllllllllllllllllll}60 & \text { M } & \text { F } & \text { G } & \text { L } & \text { K } & \text { R } & \text { R } & \text { P } & \text { R } & \text { P } & \text { S } & \text { R } & \text { S } & \text { T } & \text { T } & \text { V } & \text { P } & \text { R } & \text { Y } & \text { L } & 79\end{array}$

421 tgctggacctctatcggctacagtcgggggaggctgaggaggctggaggtcatgacattg 480

$\begin{array}{llllllllllllllllllllll}80 & \text { L } & \text { D } & \text { L } & \text { Y } & \text { R } & \text { L } & \text { Q } & \text { S } & \text { G } & \text { E } & \text { A } & \text { E } & \text { E } & \text { A } & \text { G } & \text { G } & \text { H } & \text { D } & \text { I } & \text { A } & 99\end{array}$

481 cttttgagtacccagagaggtcagccagccgagcgaacactgtgaggggcttccaccatg 540

$\begin{array}{llllllllllllllllllllll}100 & \text { F } & \text { E } & \text { Y } & \text { P } & \text { E } & \text { R } & \text { S } & \text { A } & \text { S } & \text { R } & \text { A } & \text { N } & \text { T } & \text { V } & \text { R } & \text { G } & \text { F } & \text { H } & \text { H } & \text { E } & 119\end{array}$

541 aagagcacatggagagggtgcatgagctggaggatggagagaccatgcccttcgcttcc 600

$\begin{array}{llllllllllllllllllllll}120 & \text { E } & H & \text { M } & \text { E } & \text { R } & \text { V } & \text { H } & \text { E } & \text { L } & \text { E } & \text { D } & \text { G } & \text { E } & \text { T } & \text { M } & \text { P } & \text { L } & \text { R } & \text { F } & \text { L } & 139\end{array}$

601 tgttcaacctcagcagcatcccagaggacgagctgctctcttccgccgaacttaggctct 660

$\begin{array}{llllllllllllllllllllll}140 & \text { F } & \text { N } & \text { L } & \text { S } & \text { S } & \text { I } & \text { P } & \text { E } & \text { D } & \text { E } & \text { L } & \text { L } & \text { S } & \text { S } & \text { A } & \text { E } & \text { L } & \text { R } & \text { L } & \text { Y } & 159\end{array}$

661 accgtcatcagatcgacgaggccattgctgactccctctcaggtgagcagggacttcacc 720

$\begin{array}{llllllllllllllllllllll}160 & \mathrm{R} & \mathrm{H} & \mathrm{Q} & \mathrm{I} & \mathrm{D} & \mathrm{E} & \mathrm{A} & \mathrm{I} & \mathrm{A} & \mathrm{D} & \mathrm{S} & \mathrm{L} & \mathrm{S} & \mathrm{G} & \mathrm{E} & \mathrm{Q} & \mathrm{G} & \mathrm{L} & \mathrm{H} & \mathrm{R} & 179\end{array}$

721 ggataaacgtgtatgaggtgttgaagccccegcggcccgggcagctgatcacgcagctct 780

$\begin{array}{llllllllllllllllllllll}180 & \text { I } & \text { N } & \text { V } & \text { Y } & \text { E } & \text { V } & \text { L } & \text { K } & \text { P } & \text { P } & \text { R } & \text { P } & \text { G } & \text { Q } & \text { L } & \text { I } & \text { T } & \text { Q } & \text { L } & \text { L } & 199\end{array}$

781 tggatacgcggctcgtgcgccacaatacgtcgcgctgggagagcttcgacgtcagccctg 840

$\begin{array}{llllllllllllllllllllllllllll}200 & \text { D } & \text { T } & \text { R } & \text { L } & \text { V } & \text { R } & \text { H } & \text { N } & \text { T } & \text { S } & \text { R } & \text { W } & \text { E } & \text { S } & \text { F } & \text { D } & \text { V } & \text { S } & \text { P } & \text { A } & 219\end{array}$

841 ccgtgctgcgctggactcgagagcgcctcccgaattatgggctggctgtggaggttctgc 900

$\begin{array}{llllllllllllllllllllll}220 & \text { V } & \text { L } & \text { R } & \text { W } & \text { T } & \text { R } & \text { E } & \text { R } & \text { L } & \text { P } & \text { N } & \text { Y } & \text { G } & \text { L } & \text { A } & \text { V } & \text { E } & \text { V } & \text { L } & \text { H } & 239\end{array}$

901 accttaaccagacgccgcgtcaccagggecgacacgtccgcatcagtcgttcactacacc 960

$\begin{array}{llllllllllllllllllllll}240 & \text { L } & \text { N } & \text { Q } & \text { T } & \text { P } & \text { R } & \text { H } & \text { Q } & \text { G } & \text { R } & \text { H } & \text { V } & \text { R } & \text { I } & \text { S } & \text { R } & \text { S } & \text { L } & \text { H } & \text { Q } & 259\end{array}$

961 aggagcctggtgaggactgggaacagctacgcccctcctggttacctttggccatgacg 1020

$\begin{array}{llllllllllllllllllllll}260 & \text { E } & \text { P } & \text { G } & \text { E } & \text { D } & \text { W } & \text { E } & \text { Q } & \text { L } & \text { R } & \text { P } & \text { L } & \text { L } & \text { V } & \text { T } & \text { F } & \text { G } & \text { H } & \text { D } & \text { G } & 279\end{array}$

1021 gaaagggtcacccgctgacccgccggaccaagcgcagccccaagcaacggggccgtaaac 1080

$\begin{array}{llllllllllllllllllllll}280 & \text { K } & \text { G } & \text { H } & \text { P } & \text { L } & \text { T } & \text { R } & \text { R } & \text { T } & \text { K } & \text { R } & \text { S } & \text { P } & \text { K } & \text { Q } & \text { R } & \text { G } & \text { R } & \text { K } & \text { R } & 299\end{array}$

1081 gcaaccgcaactgccggcgccacgcactgtacgtagacttcagtgatgtaggctggaatg 1140

$\begin{array}{llllllllllllllllllllll}300 & \text { N } & \text { R } & \text { N } & \text { C } & \text { R } & \text { R } & \text { H } & \text { A } & \text { L } & \text { Y } & \text { V } & \text { D } & \text { F } & \text { S } & \text { D } & \text { V } & \text { G } & \text { W } & \text { N } & \text { D } & 319\end{array}$

1141 actggatagtggcgcccctggttaccaggcttattactgccacggggaatgcccetttc 1200

$\begin{array}{llllllllllllllllllllll}320 & \text { W } & \text { I } & \text { V } & \text { A } & \text { P } & \text { P } & \text { G } & \text { Y } & \text { Q } & \text { A } & \text { Y } & \text { Y } & \text { C } & \text { H } & \text { G } & \text { E } & \text { C } & \text { P } & \text { F } & \text { P } & 339\end{array}$

1201 ctctggcggatcatctgaattcaaccaaccatgccattgttcagacactggtgaactctg 1260

$\begin{array}{llllllllllllllllllllll}340 & \text { L } & \text { A } & \text { D } & \text { H } & \text { L } & \text { N } & \text { S } & \text { T } & \text { N } & \text { H } & \text { A } & \text { I } & \text { V } & \text { Q } & \text { T } & \text { L } & \text { V } & \text { N } & \text { S } & \text { V } & 359\end{array}$

1261 tgaacaacaacattcccaaggcctgctgcgtgccaacagagctcagcgccatctccatgc 1320

$\begin{array}{llllllllllllllllllllll}360 & \text { N } & \text { N } & \text { N } & \text { I } & \text { P } & \text { K } & \text { A } & \text { C } & \text { C } & \text { V } & \text { P } & \text { T } & \text { E } & \text { L } & \text { S } & \text { A } & \text { I } & \text { S } & \text { M } & \text { L } & 379\end{array}$

1321 tctacctagacgaacatgacaaggtggtcctaaaaaactaccaggaaatggtagtggagg 1380

$\begin{array}{llllllllllllllllllllll}380 & \text { Y } & \text { L } & \text { D } & \text { E } & \text { H } & \text { D } & \text { K } & \text { V } & \text { V } & \text { L } & \text { K } & \text { N } & \text { Y } & \text { Q } & \text { E } & \text { M } & \text { V } & \text { V } & \text { E } & \text { G } & 399\end{array}$

1381 gctgcggctgccgctaaCACACAAACTAACTAGAACTTGGACTTG 1425

$\begin{array}{lllllll}400 & \mathrm{C} & \mathrm{G} & \mathrm{C} & \mathrm{R} & * & 403\end{array}$ 


\section{Appendix 3: Partial sequences of BMP5}

1 gggtactcccgtgtggcacagccttaccgagcggcccctctgttaggccacagcccgca 60

$\begin{array}{llllllllllllllllllllll}1 & G & Y & S & R & \text { V } & \text { A } & \text { Q } & \text { P } & \text { Y } & \text { R } & \text { A } & \text { A } & \text { P } & \text { L } & \text { L } & \text { G } & \text { H } & \text { S } & \text { P } & \text { A } & 20\end{array}$

61 ctcaccacagcgcacgacaccaacttcctcaatgacgccgacatggtgatgagttttgtc 120 $\begin{array}{llllllllllllllllllllll}21 & \mathrm{~L} & \mathrm{~T} & \mathrm{~T} & \mathrm{~A} & \mathrm{H} & \mathrm{D} & \mathrm{T} & \mathrm{N} & \mathrm{F} & \mathrm{L} & \mathrm{N} & \mathrm{D} & \mathrm{A} & \mathrm{D} & \mathrm{M} & \mathrm{V} & \mathrm{M} & \mathrm{S} & \mathrm{F} & \mathrm{V} & 40\end{array}$

121 aatttagtggagaaagataaagatttttcccaccaacgaagacactacaaggagttccgt 180

$\begin{array}{llllllllllllllllllllll}41 & \mathrm{~N} & \text { L } & \text { V } & \text { E } & \text { K } & \text { D } & \text { K } & \text { D } & \text { F } & \text { S } & \text { H } & \text { Q } & \text { R } & \text { R } & \text { H } & \text { Y } & \text { K } & \text { E } & \text { F } & \text { R } & 60\end{array}$

181 tttgatctgactcagatcccagatggagaggcggtgacggctgcagagtttcggatctat 240

$\begin{array}{llllllllllllllllllllll}61 & \mathrm{~F} & \mathrm{D} & \mathrm{L} & \mathrm{T} & \mathrm{Q} & \mathrm{I} & \mathrm{P} & \mathrm{D} & \mathrm{G} & \mathrm{E} & \mathrm{A} & \mathrm{V} & \mathrm{T} & \mathrm{A} & \mathrm{A} & \mathrm{E} & \mathrm{F} & \mathrm{R} & \mathrm{I} & \mathrm{Y} & 80\end{array}$

241 aaggaccgcagccatgccegctacgacaatattactctcaaggtttccatatatcaagtt 300

$\begin{array}{llllllllllllllllllllll}81 & \mathrm{~K} & \mathrm{D} & \mathrm{R} & \mathrm{S} & \mathrm{H} & \mathrm{A} & \mathrm{R} & \mathrm{Y} & \mathrm{D} & \mathrm{N} & \mathrm{I} & \mathrm{T} & \mathrm{L} & \mathrm{K} & \mathrm{V} & \mathrm{S} & \mathrm{I} & \mathrm{Y} & \mathrm{Q} & \mathrm{V} & 100\end{array}$

301 atcaaggaatatcaaaacaaagatgcagagacattcttgctcgactccaaaaaggtccag 360 $\begin{array}{llllllllllllllllllllll}101 & \text { I } & \text { K } & \text { E } & \text { Y } & \text { Q } & \text { N } & \text { K } & \text { D } & \text { A } & \text { E } & \text { T } & \text { F } & \text { L } & \text { L } & \text { D } & \text { S } & \text { K } & \text { K } & \text { V } & \text { Q } & 120\end{array}$

361 gcgtccgatgggggctggctggtgtttgacatcacggccaccagtaaccactgggtgatg 420

$\begin{array}{llllllllllllllllllllll}121 & \text { A } & \text { S } & \text { D } & G & G & \text { W } & \text { L } & \text { V } & \text { F } & \text { D } & \text { I } & \text { T } & \text { A } & \text { T } & \text { S } & \text { N } & \text { H } & \text { W } & \text { V } & \text { M } & 140\end{array}$

421 aacccacagcagaacttgggcctgcagctctgtgtggagactgtagacggacgaagtatc 480

$\begin{array}{llllllllllllllllllllll}141 & N & P & Q & Q & N & \text { L } & G & \text { L } & \text { Q } & \text { L } & \text { C } & \text { V } & \text { E } & \text { T } & \text { V } & \text { D } & \text { G } & \text { R } & \text { S } & \text { I } & 160\end{array}$

481 aacataaaatctgctggaatcattgggaggaatgggccccagtccaaacagcccttcctg 540

$\begin{array}{llllllllllllllllllllll}161 & \mathrm{~N} & \text { I } & \text { K } & \text { S } & \text { A } & \text { G } & \text { I } & \text { I } & G & \text { R } & \text { N } & \text { G } & \text { P } & \text { Q } & \text { S } & \text { K } & \text { Q } & \text { P } & \text { F } & \text { L } & 180\end{array}$

541 gttgctttcttcaaggccagcggggtgttacttcgctctgtcagagctgctggtgggaag 600

$\begin{array}{llllllllllllllllllllll}181 & \text { V } & \text { A } & \text { F } & \text { F } & \text { K } & \text { A } & \text { S } & \text { G } & \text { V } & \text { L } & \text { L } & \text { R } & \text { S } & \text { V } & \text { R } & \text { A } & \text { A } & \text { G } & \text { G } & \text { K } & 200\end{array}$

601 aaaaagaaccacaatcgcaataaatctactaatcagcaagaatcatcgagggcgccaaaa 660

$\begin{array}{llllllllllllllllllllll}201 & \mathrm{~K} & \mathrm{~K} & \mathrm{~N} & \mathrm{H} & \mathrm{N} & \mathrm{R} & \mathrm{N} & \mathrm{K} & \mathrm{S} & \mathrm{T} & \mathrm{N} & \mathrm{Q} & \mathrm{Q} & \mathrm{E} & \mathrm{S} & \mathrm{S} & \mathrm{R} & \mathrm{A} & \mathrm{P} & \mathrm{K} & 220\end{array}$

661 actggagattacaacaccagtgaacagaagcaagcctgtaagaagcatgaactttatgtc 720

$\begin{array}{llllllllllllllllllllll}221 & \mathrm{~T} & G & \mathrm{D} & \mathrm{Y} & \mathrm{N} & \mathrm{T} & \mathrm{S} & \mathrm{E} & \mathrm{Q} & \mathrm{K} & \mathrm{Q} & \text { A } & \text { C } & \text { K } & \text { K } & \text { H } & \text { E } & \text { L } & \text { Y } & \text { V } & 240\end{array}$

721 agctttcgagatttgggctggcaggattggatcattgcacctgagggctacgctgctttt 780

$\begin{array}{llllllllllllllllllllll}241 & \text { S } & \text { F } & \text { R } & \text { D } & \text { L } & G & \text { W } & \text { Q } & \text { D } & \text { W } & \text { I } & \text { I } & \text { A } & \text { P } & \text { E } & \text { G } & \text { Y } & \text { A } & \text { A } & \text { F } & 260\end{array}$

781 tactgtgatggtgaatgctcgttcccactcaacgcacacatgaacgcaacaaatcatgca 840

$\begin{array}{llllllllllllllllllllll}261 & \text { Y } & \text { C } & \text { D } & \text { G } & \text { E } & \text { C } & \text { S } & \text { F } & \text { P } & \text { L } & \text { N } & \text { A } & \text { H } & \text { M } & \text { N } & \text { A } & \text { T } & \text { N } & \text { H } & \text { A } & 280\end{array}$

841 attgtgcaaaccctggtccatttaatgtttcctgaaaatgtgccaaagccgtgctgtgcc 900

$\begin{array}{llllllllllllllllllllll}281 & \mathrm{I} & \mathrm{V} & \mathrm{Q} & \mathrm{T} & \mathrm{L} & \mathrm{V} & \mathrm{H} & \mathrm{L} & \mathrm{M} & \mathrm{F} & \mathrm{P} & \mathrm{E} & \mathrm{N} & \mathrm{V} & \mathrm{P} & \mathrm{K} & \mathrm{P} & \mathrm{C} & \mathrm{C} & \mathrm{A} & 300\end{array}$

901 ccaaccaagctcaacgcaatatcagtactttactttgatgacagctcaaacgttatcctc 960

$\begin{array}{llllllllllllllllllllll}301 & \mathrm{P} & \text { T } & \text { K } & \text { L } & \text { N } & \text { A } & \text { I } & \text { S } & \text { V } & \text { L } & \text { Y } & \text { F } & \text { D } & \text { D } & \text { S } & \text { S } & \text { N } & \text { V } & \text { I } & \text { L } & 320\end{array}$

961 aagaaatacagaaatatggtagtcaggtcttgtggctgccattagTGGCTGGGCTAACTT 1020

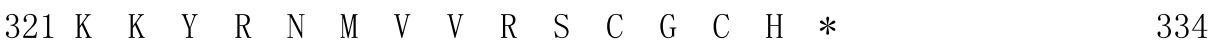

$1021 \mathrm{~T} 1021$ 


\section{Appendix 4: Partial sequences of BMP10}

1 GAAGGACAGTCCTCCCTCAAAACATTGAACTGTTTGCAAGTATCCTCTACAAAGGATCCA 60 61 TCACATCTTCTCATCTGATACTCTAAGTCTTTGGATCTAAGCTTTTCCTCCACTCAGCCa 120

1 M 1

121 tgaccgcttcagtcttctccaacctcgggtttatccgctctctgaatgtcctacttctgg 180 $\begin{array}{llllllllllllllllllllll}2 & \text { T } & \text { A } & \text { S } & \text { V } & \text { F } & \text { S } & \text { N } & \text { L } & G & \text { F } & \text { I } & R & \text { S } & \text { L } & \text { N } & \text { V } & \text { L } & \text { L } & \text { L } & \text { V } & 21\end{array}$

181 tgttgactgctgacttgagcttgagcagtcccatcaagtctcctgagaaccatcacaggg 240

$\begin{array}{lllllllllllllllllllllll}22 & \text { L } & \text { T } & \text { A } & \text { D } & \text { L } & \text { S } & \text { L } & \text { S } & \text { S } & \text { P } & \text { I } & K & \text { S } & \text { P } & \text { E } & \text { N } & \text { H } & \text { H } & \text { R } & \text { A } & 41\end{array}$

241 catcagtcggtagggatgtgggtgataatccgcttcttgatgcacaggactttctgagcc 300 $\begin{array}{llllllllllllllllllllll}42 & \text { S } & \text { V } & \text { G } & \text { R } & \text { D } & \text { V } & \text { G } & \text { D } & \text { N } & \text { P } & \text { L } & \text { L } & \text { D } & \text { A } & \text { Q } & \text { D } & \text { F } & \text { L } & \text { S } & \text { Q } & 61\end{array}$

301 agtttctgtccacactgaacctcacagagctgaggccccagccaggccctcgctgccc 360

$\begin{array}{llllllllllllllllllllll}62 & \text { F } & \text { L } & \text { S } & \text { T } & \text { L } & \text { N } & \text { L } & \text { T } & \text { E } & \text { L } & \text { R } & \text { P } & \text { Q } & \text { P } & \text { R } & \text { P } & \text { L } & \text { A } & \text { A } & \text { L } & 81\end{array}$

361 ttaaggagccaccagagtacatgttggagctgtacaaccgatttgccaatgaccgcactt 420

$\begin{array}{llllllllllllllllllllll}82 & \text { K } & \text { E } & \text { P } & \text { P } & \text { E } & \text { Y } & \text { M } & \text { L } & \text { E } & \text { L } & \text { Y } & \text { N } & \text { R } & \text { F } & \text { A } & \text { N } & \text { D } & \text { R } & \text { T } & \text { S } & 101\end{array}$

421 ctgtgccctcagccaacattgtgcgcagtttcaagaatgaagattcctcccctacagtt 480

$\begin{array}{llllllllllllllllllllll}102 & \text { V } & \text { P } & \text { S } & \text { A } & \text { N } & \text { I } & \text { V } & \text { R } & \text { S } & \text { F } & \text { K } & \text { N } & \text { E } & \text { D } & \text { S } & \text { S } & \text { P } & \text { Y } & \text { S } & \text { L } & 121\end{array}$

481 tatctgccaggggtgtaaggatacacccctgctgttcaacatctccatgcccaccatg 540

$\begin{array}{llllllllllllllllllllll}122 & \text { S } & \text { A } & \text { R } & G & \text { V } & \text { R } & \text { I } & \text { H } & \text { P } & \text { L } & \text { L } & \text { F } & \text { N } & \text { I } & \text { S } & \text { M } & \text { P } & \text { H } & \text { H } & \text { E } & 141\end{array}$

541 agcacataacaatagctgagcttcgcattttcccctgttgcggaaggcccgaaggccat 600

$\begin{array}{llllllllllllllllllllll}142 & \mathrm{H} & \mathrm{I} & \mathrm{T} & \mathrm{I} & \mathrm{A} & \mathrm{E} & \mathrm{L} & \mathrm{R} & \mathrm{I} & \mathrm{F} & \mathrm{P} & \mathrm{L} & \mathrm{L} & \mathrm{R} & \mathrm{K} & \mathrm{A} & \mathrm{R} & \mathrm{R} & \mathrm{P} & \mathrm{Y} & 161\end{array}$

601 attctggcattgactgcaaggtgaccatttacaatatacatgagggcgttgtttggacaa 660

$\begin{array}{llllllllllllllllllllll}162 & \text { S } & \text { G } & \text { I } & \text { D } & \text { C } & \text { K } & \text { V } & \text { T } & \text { I } & \text { Y } & \text { N } & \text { I } & \text { H } & \text { E } & \text { G } & \text { V } & \text { V } & \text { W } & \text { T } & \text { K } & 181\end{array}$

661 aagaggtggggaaagaagggagaaggagggatagagaggaggtggtggagatgagggatt 720

$\begin{array}{llllllllllllllllllllll}182 & E & V & G & K & E & G & R & R & R & D & R & E & E & V & V & E & M & R & D & L & 201\end{array}$

721 tggaggaactggtgacaaagcatattcgtgccaaagataacagctgggtgtcgtttgacc 780

$\begin{array}{llllllllllllllllllllll}202 & \text { E } & \text { E } & \text { L } & \text { V } & \text { T } & \text { K } & \text { H } & \text { I } & \text { R } & \text { A } & \text { K } & \text { D } & \text { N } & \text { S } & \text { W } & \text { V } & \text { S } & \text { F } & \text { D } & \text { L } & 221\end{array}$

781 tgactcatgtggttacactctggcggaaatctgggtgtgcaactcacagactggaggttc 840

$\begin{array}{llllllllllllllllllllll}222 & \text { T } & \text { H } & \text { V } & \text { V } & \text { T } & \text { L } & \text { W } & \text { R } & \text { K } & \text { S } & \text { G } & \text { C } & \text { A } & \text { T } & \text { H } & \text { R } & \text { L } & \text { E } & \text { V } & \text { H } & 241\end{array}$

841 acattgcaagtctggggtcagaggaggaaggggccacacaagaggtcacagaggagggtg 900

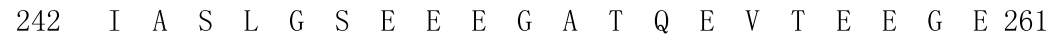

901 aagatttggtagagattgatatcgacaggagcttggagggaaacacaatgcagtgatta 960

$\begin{array}{llllllllllllllllllllll}262 & \mathrm{D} & \mathrm{L} & \mathrm{V} & \mathrm{E} & \mathrm{I} & \mathrm{D} & \mathrm{I} & \mathrm{D} & \mathrm{R} & \mathrm{S} & \mathrm{L} & \mathrm{E} & \mathrm{G} & \mathrm{K} & \mathrm{H} & \mathrm{N} & \mathrm{A} & \mathrm{V} & \mathrm{I} & \mathrm{I} & 281\end{array}$

961 tagtattctcagatgatcagagaagagagcacaaacaggatcaacaagagctcaaccaga 1020

$\begin{array}{llllllllllllllllllllll}282 & \text { V } & \text { F } & \text { S } & \text { D } & \text { D } & \text { Q } & \text { R } & \text { R } & \text { E } & \text { H } & \text { K } & \text { Q } & \text { D } & \text { Q } & \text { Q } & \text { E } & \text { L } & \text { N } & \text { Q } & \text { M } & 301\end{array}$

1021 tgattgaacatgagaatgaccttccagaaaacatgggccggagccaacaagctttctggg 1080

$\begin{array}{llllllllllllllllllllll}302 & \text { I } & \text { E } & H & \text { E } & \text { N } & \text { D } & \text { L } & \text { P } & \text { E } & \text { N } & \text { M } & \text { G } & \text { R } & \text { S } & \text { Q } & \text { Q } & \text { A } & \text { F } & \text { W } & \text { G } & 321\end{array}$

1081 ggcacgttgatcacaacactggccacgctaaccaggacgagctggacaaacagtccetca 1140

$\begin{array}{lllllllllllllllllllllll}322 & H & \text { V } & \text { D } & \text { H } & \text { N } & \text { T } & \text { G } & \text { H } & \text { A } & \text { N } & \text { Q } & \text { D } & \text { E } & \text { L } & \text { D } & \text { K } & \text { Q } & \text { S } & \text { L } & \text { M } & 341\end{array}$

1141 tgcaactgcagtccaacgttatctatgacacacctccccgaatccgtcgcaatgttaaga 1200

$\begin{array}{llllllllllllllllllllll}342 & \text { Q } & \text { L } & \text { Q } & \text { S } & \text { N } & \text { V } & \text { I } & \text { Y } & \text { D } & \text { T } & \text { P } & \text { P } & \text { R } & \text { I } & \text { R } & \text { R } & \text { N } & \text { V } & \text { K } & \text { S } & 361\end{array}$

1201 gcgagccatgcaagaggacccactctttgtggattttaaagacattggctgggattcgt 1260

$\begin{array}{llllllllllllllllllllll}362 & \text { E } & \text { P } & \text { C } & \text { K } & \text { R } & \text { T } & \text { P } & \text { L } & \text { F } & \text { V } & \text { D } & \text { F } & \text { K } & \text { D } & \text { I } & \text { G } & \text { W } & \text { D } & \text { S } & \text { W } & 381\end{array}$

1261 ggatcatccagcctctgggctacgaggcgtatgagtgcaacggtgtgtgcaacccaccta 1320

$\begin{array}{llllllllllllllllllllll}382 & \text { I } & \text { I } & \text { Q } & \text { P } & \text { L } & G & \text { Y } & \text { E } & \text { A } & \text { Y } & \text { E } & \text { C } & \text { N } & \text { G } & \text { V } & \text { C } & \text { N } & \text { P } & \text { P } & \text { M } & 401\end{array}$

1321 tgacctccgaggtctcgcctaccaaacacgccatagtgcagactctgctgagtgttaaga 1380

$\begin{array}{llllllllllllllllllllll}402 & \mathrm{~T} & \mathrm{~S} & \mathrm{E} & \mathrm{V} & \mathrm{S} & \mathrm{P} & \mathrm{T} & \mathrm{K} & \mathrm{H} & \mathrm{A} & \mathrm{I} & \mathrm{V} & \mathrm{Q} & \mathrm{T} & \mathrm{L} & \mathrm{L} & \mathrm{S} & \mathrm{V} & \mathrm{K} & \mathrm{S} & 421\end{array}$

1381 gtccagagagagcatcgcgtgcctgctgtgtacccactaagttggagccgatctcactcc 1440

$\begin{array}{llllllllllllllllllllll}422 & \text { P } & \text { E } & \text { R } & \text { A } & \text { S } & R & \text { A } & \text { C } & \text { C } & \text { V } & \text { P } & \text { T } & \text { K } & \text { L } & \text { E } & \text { P } & \text { I } & \text { S } & \text { L } & \text { L } & 441\end{array}$

1441 tttatcatgataatggggtgatcactttcaaccacaagtatgaggggatggtggtggcag 1500

$\begin{array}{lllllllllllllllllllllll}442 & \text { Y } & H & D & N & G & \text { V } & \text { I } & \text { T } & \text { F } & \text { N } & \text { H } & \text { K } & \text { Y } & \text { E } & \text { G } & \text { M } & \text { V } & \text { V } & \text { A } & \text { E } & 461\end{array}$

1501 agtgtggatgcagatagTCCTGAAAGTGATGCTATTACACAGAGATAGAGACTGCACATC 1560

462 C $G$ G $\quad$ R $*$ 465

1561 GCACACATCCTCTCATGTGCTTCTTTCCACAATATCTAAGATCTCATACAGTGGCGTGTA 1620

1621 AAAACACAAGTCTGGACTTAGTTGTAAATTAGTGCACACAAATCTGTGCTACATGATGTA 1680

1681 AATTTGCAATTGTATAAAGGTAAATCAGTTATTATATTAATGTAGAATATAAAGCAAAGC 1740

1741 AATGCTGCA 1749 
Received: 14 October 2015 Accepted: 23 August 2016 Published online: 02 September 2016

\section{References}

Alaee F, Hong SH, Dukas AG, Pensak MJ, Rowe DW, Lieberman JR (2014) Evaluation of osteogenic cell differentiation in response to bone morphogenetic protein or demineralized bone matric in a critical size defect model using GFP reporter mice. J Orthop Res 32:1120-1128

Alderdice DF, Velsen FPJ (1971) Some effects of salinity and temperature on early development of Pacific herring (Clupea pallasi). J Fish Res Board Can 28:1545-1562

Andrades JA, Becerra J, Fernández-Llebrez P (1996) Skeletal deformities in larval, juvenile and adult stages of cultured gilthead sea bream (Sparus aurata L.). Aquaculture 141:1-11

Bailon-Plaza A, Lee AO, Veson EC, Farnum CE, van der Meulen MC (1999) Bmp-5 deficiency alters chondrocytic activity in the mouse proximal tibial growth plate. Bone 24:211-216

Barahona-Fernandes MH (1982) Body deformation in hatchery reared European sea bass Dicentrarchus labrax (L). Types, prevalence and effect on fish survival. J Fish Biol 21:239-249

Baras E, Raynaud T, Slembrouck J, Caruso D, Cochet C, Legendre M (2011) Interactions between temperature and size on the growth, size heterogeneity, mortality and cannibalism in cultured larvae and juveniles of the Asian catfish, Pangasianodon hypophthalmus (Sauvage). Aquacult Res 42:260-276

Bidwell DA, Howell WH (2001) The effect of temperature on first feeding, growth, and survival of larval witch flounder Glyptocephalus cynoglossus. J. World Aquac Soc 32:373-384

Bland RJ (2001) Isolation, characterisation and evolution of zebrafish (Danio rerio) bmp9, bmp 10, and gdf11. University of Auckland, New Zealand, $\mathrm{p}$ 334

Boglione C, Gavaia P, Koumoundouros G, Gisbert E, Moren M, Fontagne S, Witten PE (2013a) Skeletal anomalies in reared European fish larvae and juveniles. Part 1: normal and anomalous skeletogenic processes. Rev. Aquac. 5:S99-S120

Boglione C, Gisbert E, Gavaia P, Witten PE, Moren M, Fontagne S, Koumoundouros G (2013b) Skeletal anomalies in reared European fish larvae and juveniles. Part 2: main typologies, occurrences and causative factors. Rev Aquacult 5:S121-S167

Breur GJ, Vanenkevort BA, Farnum CE, Wilsman NJ (1991) Linear relationship between the volume of hypertrophic chondrocytes and the rate of longitudinal bone-growth plates. Jounral of Orthopaedic Research 9:348-359

Cahu C, Zambonino Infante J, Takeuchi T (2003a) Nutritional components affecting skeletal development in fish larvae. Aquaculture 227:245-258

Cahu CL, Infante JLZ, Barbosa V (2003b) Effect of dietary phospholipid level and phospholipid: neutral lipid value on the development of sea bass (Dicentrarchus labrax) larvae fed a compound diet. British J. Nutr. 90:21-28

Canalis E, Economides AN, Gazzerro E (2003) Bone morphogenetic proteins, their antagonists, and the skeleton. Endocr Rev 24:218-235

Choa BY, Carter CG, Battaglene SC (2010) Effects of temperature regime on growth and development of post-larval striped trumpeter (Latris lineata). Aquaculture 305:95-101

Cobcroft JM, Pankhurst PM, Poortenaar C, Hickman B, Tait M (2004) Jaw malformation in cultured yellowtail kingfish (Seriola lalandi) larvae. NZ J Mar Freshw Res 38:67-71

Cobcroft J, Shu-chien A, Kuah M, Jaya-Ram A, Battaglene S (2012) The effects of tank colour, live food enrichment and greenwater on the early onset of jaw malformation in striped trumpeter larvae. Aquaculture 356-357:61-72

Dale L, Johns CM (1999) BMP signaling in early Xenopus development. BioEssays $21: 751-760$

Fielder DS, Bardsley WJ, Allan GL, Pankhurst PM (2005) The effects of salinity and temperature on growth and survival of Australian snapper, Pagrus auratus larvae. Aquaculture 250:201-214

Gardeur JN, Mathis N, Kobilinsky A, Brun-Bellut J (2007) Stimultaneous effects of nutritional and environmental factors on growth and flesh quality of Perca fluviatilis using a fractional factorial design study. Aquaculture 273:50-63
Georgakopoulou E, Angelopoulou A, Kaspiris P, Divanach P, Koumoundouros G (2007) Temperature effects on cranial deformities in European sea bass, Dicentrarchus labrax (L.). J Appl Ichthyol 23:99-103

Glozak MA, Rogers MB (1996) Specific induction of apoptosis in P19 embryonal carcinoma cells by retinoic acid and BMP2 or BMP4. Dev Biol 179:458-470

Graff JM (1997) Embryonic patterning: to BMP or not to BMP, that is the question. Cell 89:171-174

Graham MA, Francis-West P, Brickell P, Lumsden A (1994) The signalling molecule BMP4 mediates apoptosis in the rhombencephalic neural crest. Nature 372:684-686

Grgurevic L, Macek B, Mercep M, Jelic M, Smoljanovic T, Erjavec I, Dumic-Cule I, Prgomet S, Durdevic D, Vnuk D, Lipar M, Stejskal M, Kufner V, Brkljacic J, Maticic D, Vukicevic S (2011) Bone morphogenetic protein (BMP)1-3 enhances bone repair. Biochem Biophys Res Commun 408:25-31

Guo H, Ma Z, Jiang S, Zhang D, Zhang N, Li Y (2014) Length-weight relationship of oval pompano, Trachinotus ovatus (Linnaeus 1758) (Pisces; Carangidae) cultured in open sea floating sea cages in South China Sea. Indian J Fish 61:93-95

Hogan BLM (1996a) Bone morphogenetic proteins in development. Curr Opin Genet Dev 6:432-438

Hogan BLM (1996b) Bone morphogenetic proteins: multifunctional regulators of vertebrate development. Genes Development 10:1580-1594

Hopkins KD (1992) Reporting fish growth: a review of the basics. J World Aquacult Soc 23:173-179

Jobling M (1994) Fish bioenergetic. Chapman and Hall, London

Kamler E (1992) Early life history of fish: An energetics approach. Chapman and Hall, London

Karsenty G, Wagner EF (2002) Reaching a genetic and molecular understanding of skeletal development. Dev Cell 2:389-406

Keckeis H, Kamler E, Bauer-Nemeschkal E, Schneeweiss K (2001) Survival, development and food energy partitioning of nase larvae and early juveniles at different temperatures. J Fish Biol 59:45-61

Kestemont P, Baras E (2001) Environmental Factors and Feed Intake: Mechanisms and Interactions. In: Houlihan D, Boujard T, Jobling M (eds) Food intake in fish. Blackwell Science, Cornwall, pp 131-156

Kim RY, Robertson EJ, Solloway MJ (2001) Bmp6 and Bmp7 are required for cushion formation and septation in the developing mouse heart. Dev Biol 235:449-466

King JA, Marker PC, Seung KJ, Kingsley DM (1994) Bmp5 and the molecular, skeletal, and soft-tissue alterations in short ear mice. Dev Biol 166:112-122

Kingsley DM, Bland AE, Grubber JM, Marker PC, Russell LB, Copeland NG, Jenkins NA (1992) The mouse short ear skeletal morphogenesis locus is associated with defects in a bone morphogenetic member of the tgf beta superfamily. Cell 71:399-410

Kishimoto Y, Lee K, Zon L, Hammerschmidt M, Schulte-Merker S (1997) The molecular nature of zebrafish swirl: BMP2 function is essential during early dorsoventral patterning. Development 124:4457-4466

Koumoundouros G (2010) Morpho-anatomical abnormalities in Mediterranean marine aquaculture. In: Koumoundouros $\mathrm{G}$ (ed) Recent advances in aquaculture research. Transworld Research Network, Kerala, Indian, pp $125-148$

Lein I, Holmefjord I, Rye M (1997) Effects of temperature on yolk sac larvae of Atlantic halibut (Hippoglossus hippoglossus L.). Aquaculture 157:123-135

Ludwig GM, Lochmann SE (2009) Effect of temperature on larval sunshine bass growth and survival to the fingerling stage. N Am J Aqualcult $71: 260-266$

Ma Z (2014) Food ingestion, prey selectivity, feeding incidence, and performance of yellowtail kingfish Seriola lalandi larvae under constant and varying temperatures. Aquacult Int 22:1317-1330

Ma Z, Qin JG, Nie Z (2012) Morphological changes of marine fish larvae and their nutrition need. In: Pourali K, Raad VN (eds) Larvae: morphology, biology and life cycle. Nova Science Publishers Inc., New York, pp 1-20

Ma Z, Guo H, Zhang D, Hu CQ, Jiang S (2014a) Food ingestion, consumption, and selectivity of pompano, Trachinotus ovatus (Linnaeus 1758) under different rotifer densities. Aquacult Res. doi:10.1111/are.12413

Ma Z, Guo H, Zheng P, Wang L, Jiang S, Qin JG, Zhang D (2014b) Ontogenetic development of digestive functionality in golden pompano Trachinotus ovatus (Linnaeus 1758). Fish Physiol Biochem 40:1157-1167 
Ma Z, Zheng P, Guo H, Zhang N, Jiang S, Zhang D, Qin JG (2014c) Jaw malfromation of hatchery reared golden pompano Trachinotus ovatus (Linnaeus 1758) larvae. Aquacult Res. doi:10.1111/are.12569

Ma Z, Zheng P, Guo H, Zhang N, Wang L, Jiang S, Qin JG, Zhang D (2014d) Effect of weaning time on the performance of Trachinotus ovatus (Linnaeus 1758) larvae. Aquac Nutr. doi:10.1111/anu.12183

Marques CL, Fernandez I, Rosa J, Viegas MN, Cancela ML, Laize V (2014) Spatiotemporal expression and retinoic acid regulation of bone morphogenetic proteins 2, 4 and 16 in Senegalese sole. J Appl Ichthyol 30:713-720

Marques CL, Fernández I, Viegas MN, Cox CJ, Martel P, Rosa J, Cancela ML, Laizé $\checkmark$ (2015) Comparative analysis of zebrafish bone morphogenetic proteins 2, 4 and 16: molecular and evolutionary perspectives. Cell Mol Life Sci. doi:10.1007/s00018-015-2024-x

Martell DJ, Kieffer JD, Trippel EA (2005) Effect of temperature during early life history on embrypnic and larval development and growth in haddock. Fish Biol 66:1558-1575

McGurk MD (1984) Effects of delayed feeding and temperature on the age of irreversible starvation and on the rates of growth and mortality of Pacific herring larvae. Mar Biol 84:13-26

Mehler MF, Mabie PC, Zhang D, Kessler JA (1997) Bone morphogenetic proteins. Trends Neurosci 20:309-317

Minina E, Wenzel HM, Karp S, Gaffield W, McMahon AP, Vortkamp A (2001) BMP and Ihh/PTHrP signaling interact to coordinate chondrocyte proliferation and differentiation. Development 128:4523-4534

Myers DC, Sepich DS, Solnica-Krezel L (2002) Bmp Activity Gradient Regulates Convergent Extension during Zebrafish Gastrulation. Dev Biol 243:81-98

Neuhaus H, Rosen V, Thies RS (1999) Heart specific expression of mouse BMP10 a novel member of the TGF- $\beta$ superfamily. Mech Dev 80:181-184

Nijweide PJ, Burger EH, Feyen JH (1986) Cells of bone: proliferation, differentiation, and hormonal regulation. Physiol Rev 66:855-886

Ørnsrud R, Gil L, Waagbø R (2004) Teratogenicity of elevated egg incubation temperature and egg vitamin A status in Atlantic salmon. Salmo salar L. J. Fish Dis. 27:213-223

Otterlei E, Nyhammer G, Folkvord A, Stefansson SO (1999) Temperature- and size- dependent growth of larval and early juvenile Atlantic cod (Gadus morhua): a comparative study of Norwegian coastal cod and northeast Arctic cod. Can J Fish. Aquacult Sci 56:2099-2111

Palomino J, Herrera G, Dettleff P, Martinez V (2014) Growth differentiation factor 9 and bone morphogenetic protein 15 expression in previtellogenic oocytes and during early embryonic development of Yellow-tail Kingfish Seriola lalandi. Biol Res 47:1-7

Phan TCA, Xu J, Zheng MH (2004) Interaction between osteoblast and osteoclast: impact in bone diease. Histol Histopathol 19:1325-1344

Prestinicola L, Boglione C, Makridis P, Spano A, Rimatori V, Palamara E, Scardi M, Cataudella S (2013) Environmental conditioning of skeletal anomalies typology and frequency in gilthead seabream (Sparus aurata L., 1758) juveniles. PLoS One 8:1-22

Razdorov G, Vukicevic S (2012) The Use of Mass Spectrometry in Characterization of Bone Morphogenetic Protein from Biological Samples. In: Prasain JK (ed) Trandem mass spectrometry - applications and principles. InTech, Rijeka, Croatia, pp 259-284

Rickard DJ, Sullivan TA, Shenker BJ, Leboy PS, Kazhdan I (1994) Induction of rapid osteoblast differentiation in rat bone marrow stromal cell cultures by dexamethasone and BMP-2. Dev Biol 161:218-228

Riley KL, Weirich CR, Cerino D (2009) Development and growth of hatchery-reared larval Florida pompano (Trachinotus carolinus). Fish Bull 107:318-328

Rombough PJ (1997) The effects of temperature on embryonic and larval development. In: Wood CM, McDonald DG (eds) Global Warming. Cambridge University Press, Cambridge, Implications for Freshwater and Marine Fish, pp 177-223

Shi Y, Massague J (2003) Mechanisms of TGF- $\beta$ signaling from cell membrane to the nucleus. Cell 113:695-700
Solloway MJ, Robertson EJ (1999) Early embryonic lethality in Bmp5; Bmp7 double mutant mice suggests functional redundancy within the $60 \mathrm{~A}$ subgroup. Development 126:1753-1768

Storm EE, Huynh TV, Copeland NG, Jenkins NA, Kingsley DM, Lee SJ (1994) Limb alterations in brachypodism mice due to mutations in a new member of the tgf beta-superfamily. Nature 368:639-643

Tiago DM, Marques CL, Roberto VP, Cancela ML, Laize V (2014) Mir-20a regulates in vitro mineralization and BMP signaling pathway by targeting BMP-2 transcript in fish. Arch Biochem Biophys 543:23-30

Vainio S, Karavanova I, Jowett A, Thesleff I (1993) Identification of BMP-4 as a signal mediating secondary induction between epithelial and mesenchymal tissues during early tooth development. Cell 75:45-58

Villeneuve L, Gisbert E, Delliou HL, Cahu CL, Zambonino-Infante JL (2005a) Dietary levels of all-trans retinol affect retinoid nuclear receptor expression and skeletal development in European sea bass larvae. Br J Nutr 93:791-801

Villeneuve L, Gisbert E, Zambonino-Infante JL, Quazuguel P, Cahu CL (2005b) Effect of nature of dietary lipids on European sea bass morphogenesis: implication of retinoid receptors. Br J Nutr 94:877-884

Villeneuve LAN, Gisbert E, Moriceau J, Cahu CL, Zambonino JL (2006) Intanke of high levels of vitamin A and polyunsaturated fatty acids during different developmental periods modifies the expression of morphogenesis genes in European sea bass (Dicentrarchus labrax). Br J Nutr 95:677-687

Von Westernhagen $H$ (1988) Sublethal effects of pollutants on fish eggs and larvae. In: Hoar WS, Randall DJ (eds) Fish physiology. Academic Press INC, San Diego

Wan M, Cao X (2005) BMP signaling in skeletal development. Biochem. Biophys. Res. Commun. 328:651-657

Wen W, Huang X, Chen Q, Feng L, Wei L (2013) Temperature effects on early development and biochemical dynamics of a marine fish, Inimicus japonicus. J Exp Mar Biol Ecol 442:22-29

Whitman M (1998) Smads and early developmental signaling by the TGF- $\beta$ super-family. Genes Dev 12:2445-2462

Windhausen T, Squifflet S, Renn J, Muller M (2015) BMP signaling regulates bone morphogenesis in zebrafish through promoting osteoblast function as assessed by their nitric oxide production. Molecules 20:7586-7601

Wolfman NM, MCPherron AC, Pappano WN, Davies MV, Song K, Tomkinson KN, Wright JF, Zhao L, Sebald SM, Greenspan DS, Lee SJ (2003) Activation of latent myostatin by the bmp-1/tolloid family of metalloproteinases. Proc Natl Acad Sci USA 100:15842-15846

Ytteborg E, Baeverford G, Torgersen J, Hjelde K, Takle H (2010) Molecular pathology of vertebral deformities in hyperthermic Atlantic salmone (Salmo salar). BMC Phy 10:1-16

Zheng P, Ma Z, Guo H, Zhang D, Fu M, Zhang N, Jiang S (2014) Osteological ontogeny and malformations in larval and juvenile golden pompano Trachinotus ovatus (Linnaeu 1758). Aquacult Res. doi:10.1111/are.12600

Zou H, Niswander L (1996) Requirement for BMP signaling in interdigital apoptosis and scale formation. Science 272:738-741

\section{Submit your manuscript to a SpringerOpen ${ }^{\circ}$ journal and benefit from:}

- Convenient online submission

- Rigorous peer review

- Immediate publication on acceptance

- Open access: articles freely available online

- High visibility within the field

- Retaining the copyright to your article

Submit your next manuscript at springeropen.com 